\title{
Soil correction for planting bermudagrass using steel slag or limestone
}

\author{
Mauricio Roberto de Oliveira ${ }^{1}$ (D), Dirceu Maximino Fernandes ${ }^{1}$ (D), Roberto Lyra Villas Bôas ${ }^{1}$ (D), Clarice Backes $^{2}$ (D), \\ Leandro José Grava de Godoy ${ }^{3}$, Alessandro José Marques do Santos $^{2} \mathbb{D}$ \\ ${ }^{1}$ Universidade Estadual Paulista (Unesp), Faculdade de Ciências Agronômicas, Botucatu-SP, Brazil. \\ ${ }^{2}$ Universidade Estadual de Goiás (UEG), Departamento de Zootecnia, São Luís de Montes Belos-GO, Brazil. \\ ${ }^{3}$ Universidade Estadual Paulista (Unesp), Câmpus de Registro, Registro-SP, Brazil.
}

\begin{abstract}
Limestone is the most commonly used acidity-correction agent in tropical soils. However, steel slag can be an alternative for turfgrass production areas because it contains silicon, which can increase turfgrass tolerance to biotic and/or abiotic stresses. This study was developed to evaluate the effect of the application of steel slag, as compared with limestone, on a bermudagrass sod production system. The experiment was carried out in Botucatu-SP, Brazil, in a randomized block design arranged in a factorial scheme $2 \times 5$ with 4 replications. Treatments consisted of two correctives (steel slag and limestone) and their rates, which were calculated to raise the soil base saturation to $12 \%$ (current), 30\%, 50\%, 70\% and 90\%. The application of lime and steel slag rates had positive effects on soil chemical attributes related to acidity correction, such as $\mathrm{pH}, \mathrm{Ca}, \mathrm{Mg}, \mathrm{H}+\mathrm{Al}, \mathrm{Al}, \mathrm{CEC}, \mathrm{SB}$, and base saturation (\%). The slag provided higher levels of $\mathrm{P}, \mathrm{Ca}$, and $\mathrm{Si}$, whereas limestone increased the $\mathrm{Mg}$ soil content. Steel slag provided a higher ground cover rate for bermudagrass than limestone at 114 and 161 days after transplanting (DAT), with maximum cover rate achieved with $60 \%$ base saturation at 161 DAT. The turfgrasses treated with slag showed a higher amount of roots, rhizomes, and stolons when compared with those treated with limestone. It is suggested the use of steel slag and, in calculating the need for corrective, $90 \%$ soil base saturation.
\end{abstract}

Keywords: Cynodon sp., lawn, liming, silicon.

\section{Resumo}

Correção do solo para plantio de grama bermuda utilizando escória de aciaria ou calcário

O corretivo de acidez mais comumente utilizado nos solos tropicais é o calcário, porém a escória de aciaria pode ser alternativa para áreas de produção de grama, devido à presença do silício que pode aumentar a tolerância da grama a estresses bióticos e/ou abióticos. Este estudo foi desenvolvido para avaliar o efeito da aplicação de escória de aciaria, comparado ao calcário, na implantação de um sistema de produção de grama bermuda. O experimento foi instalado em Botucatu-SP e o delineamento experimental utilizado foi em blocos ao acaso em fatorial 2 x 5 com 4 repetições. Os tratamentos foram compostos por dois corretivos (escória de aciaria e calcário) e doses dos corretivos calculados para elevar as saturações por bases do solo para $12 \%$ (atual), 30\%, 50\%, 70\% e $90 \%$. A aplicação de doses de calcário e de escória de aciaria proporcionaram efeitos positivos nos atributos químicos do solo relacionados com a correção da acidez, como o pH, teores de $\mathrm{Ca}$ e $\mathrm{Mg}, \mathrm{H}+\mathrm{Al}, \mathrm{Al}, \mathrm{CTC}, \mathrm{SB}$, e V\%. A escória proporcionou maiores teores de P, $\mathrm{Ca}$ e $\mathrm{Si}$, enquanto o calcário maior teor de $\mathrm{Mg}$ no solo. A escória de aciaria proporcionou uma maior taxa de cobertura do solo pela grama bermuda quando comparado ao calcário, aos 114 e 161 DAT (dias após o transplantio), sendo a máxima taxa de cobertura obtida com a saturação por bases de $60 \%$ aos 161 DAT. As gramas que receberam a escória apresentaram maior quantidade de raízes, rizomas e estolões, quando comparados ao calcário. Sugere-se o uso da escoria de siderurgia, e, no cálculo da necessidade de corretivo, a saturação por bases do solo de $90 \%$.

Palavras chave: Cynodon sp,gramado, calagem, silício.

\footnotetext{
*Corresponding author: leandro.godoy@unesp.br 


\section{Introduction}

The Brazilian market of cultivated turfgrasses has considerably expansion due to the increasing demand for this crop in landscape and for sports areas. Its growth could be further intensified if there was a reduction in the extraction of native grass, which, according to Antoniolli (2015), is a product with no quality that causes environmental impacts owing to extractivism.

To maximize turfgrass production in an economical manner, two aspects must be considered: the production of high-quality turfgrass that maintains the sod whole to be transplanted, which, according to Lima et al. (2018) is directly related to the production of roots, rhizomes and stolons; and the shortest possible production time, with a short interval between harvests.

For the crop reaches its potential, good soil fertility is required, as a nutrient-demanding crop. Lima et al. (2015) found that, to reach $100 \%$ of ground cover, bermudagrass required approximately $219.5,27,174.1,31.8,13.4$, and $39.9 \mathrm{~kg} \mathrm{ha}^{-1}$ of $\mathrm{N}, \mathrm{P}, \mathrm{K}, \mathrm{Ca}, \mathrm{Mg}$, and $\mathrm{S}$, respectively, disregarding losses in the system.

However, since most of the cultivated soils have an excessive acid reaction, nutrient availability is reduced (Rodrighero et al., 2015), which directly interferes with the productive efficiency of plants.

Although limestone is the most used soil-acidity corrective, other materials, such as steel slag (silicate), have been tested as corrective agents and shown efficient results. The application of silicate provides positive effects on the chemical attributes of the soil related to acidity correction, e.g., $\mathrm{pH}, \mathrm{Ca}$ and $\mathrm{Mg}$ contents, CEC and SB (Alovisi et al., 2018), besides increasing the availability of $P$ in the soil when compared with limestone (Souza and Chaves, 2015).

In addition to correcting acidity, in grass production areas, silicate is a source of Si that can allow a reduction in irrigation frequency, increase the tolerance of the grass to high and low temperatures, increase the resistance of the grass to pests and diseases and even increase the resistance of lawns against trampling (Godoy et al., 2012).

Information about soil correction in grass production systems is scarce. On this basis, this study proposes to examine the effect of the application of steel slag, as compared with limestone, on the implementation of a bermudagrass (Cynodon sp) production system.

\section{Material and methods}

The experiment was conducted in Botucatu-SP, Brazil (22 $51^{\prime} \mathrm{S}$ and $48^{\circ} 26^{\prime} \mathrm{W}$, average altitude of $786 \mathrm{~m}$ and average slope of $3 \%$ ), whose climate is characterized as hot humid subtropical (Cfa) type, according to the Köppen classification, characterized by an average temperature of over $22{ }^{\circ} \mathrm{C}$ in the hottest month (Cunha and Martins, 2009). Temperature and precipitation data collected during the experiment are shown in Figure 1.
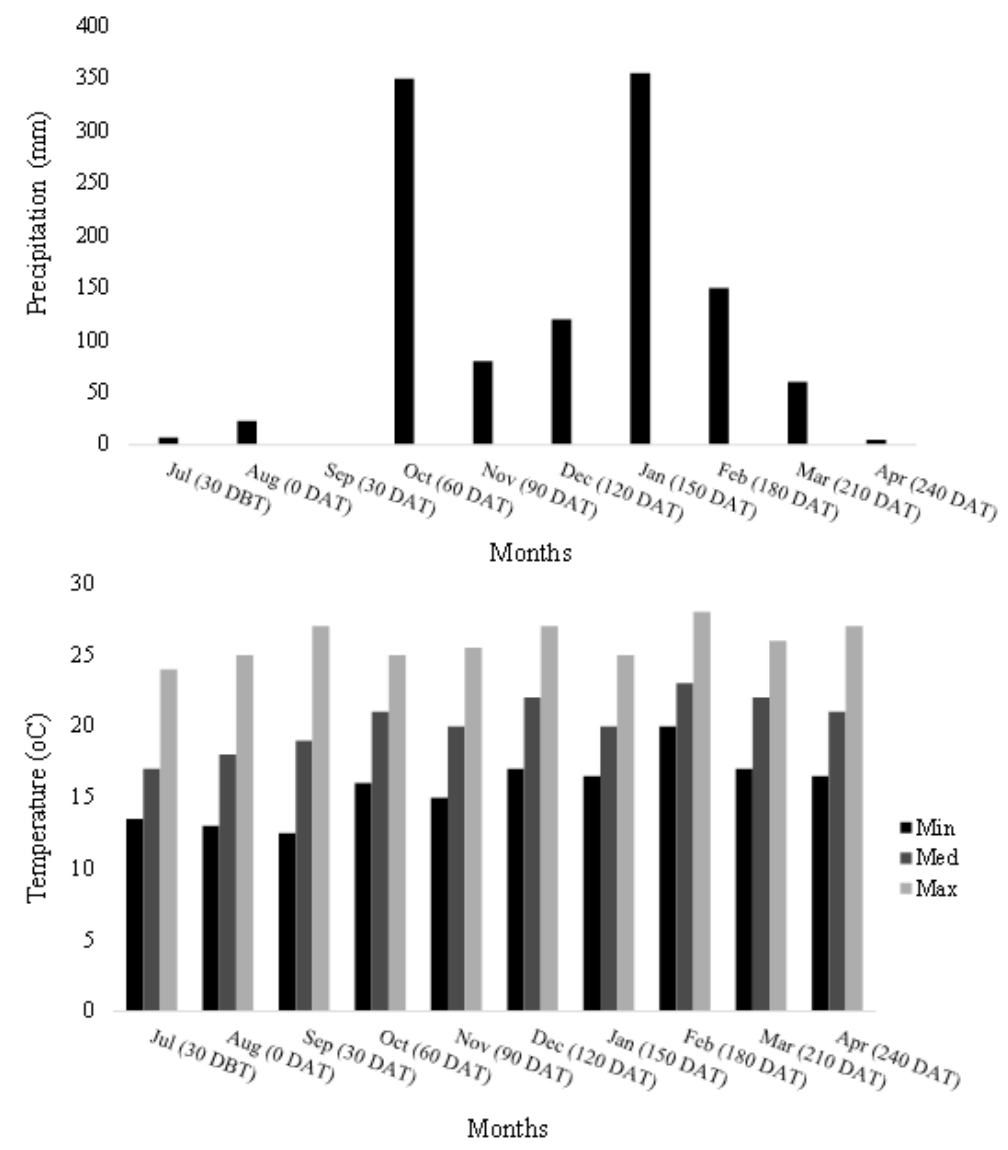

Figure 1. Precipitation and minimum, medium and maximum temperature data during the experimental period. DBT - days before transplantation; DAT - days after transplantation. 
The soil was classified as a Dystrophic Red Latosol, on smooth undulating relief (Santos et al., 2018). For an initial chemical characterization, samples were collected throughout the experimental area from the $0-0.10$ and $0.10-0.20$ m-deep layers, whose analysis results are shown in Table 1. According to the textural analysis, the sand, silt and clay contents were 322,182 and $496 \mathrm{~g} \mathrm{~kg}^{-1}$, respectively, in the 0.0-0.10 m layer; and 308,182 and $510 \mathrm{~g} \mathrm{~kg}^{-1}$ in the $0.10-0.20 \mathrm{~m}$ layer.

Table 1. Chemical characteristics of the Dystrophic Red Latosol before the installation of the experiment with bermudagrass.

\begin{tabular}{|c|c|c|c|c|c|c|c|c|c|c|c|}
\hline Layer & pH & OM & $\mathbf{P}_{\text {resin }}$ & $\mathbf{H}+\mathbf{A l}$ & $\mathbf{K}$ & $\mathbf{C a}$ & Mg & SB & CEC & BS\% & Si \\
\hline $\mathrm{m}$ & $\mathrm{CaCl}_{2}$ & $\mathrm{~g} \mathrm{dm}^{-3}$ & $\begin{array}{c}\mathrm{mg} \\
\mathrm{dm}^{-3}\end{array}$ & \multicolumn{7}{|c|}{ 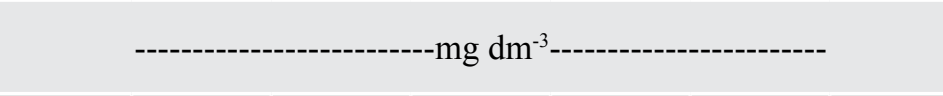 } & $\underset{\mathrm{dm}^{-3}}{\mathrm{mg}}$ \\
\hline $0.0-0.10$ & 4.1 & 20 & 2 & 91 & 1.3 & 8.5 & 3.5 & 13 & 104 & 12 & 0.8 \\
\hline \multirow[t]{2}{*}{$0.10-0.20$} & 4.1 & 18 & 2 & 87 & 0.9 & 7 & 2 & 10 & 98 & 10 & 0.7 \\
\hline & \multicolumn{3}{|c|}{ B } & \multicolumn{2}{|c|}{$\mathrm{Cu}$} & \multicolumn{2}{|c|}{$\mathrm{Fe}$} & \multicolumn{2}{|c|}{$\mathrm{Mn}$} & \multicolumn{2}{|c|}{$\mathrm{Zn}$} \\
\hline $\mathrm{m}$ & \multicolumn{11}{|c|}{------------- } \\
\hline $0.0-0.10$ & \multicolumn{3}{|c|}{0.32} & \multicolumn{2}{|c|}{6.6} & \multicolumn{2}{|c|}{46} & \multicolumn{2}{|c|}{15.5} & \multicolumn{2}{|c|}{0.6} \\
\hline $0.10-0.20$ & \multicolumn{3}{|c|}{0.35} & \multicolumn{2}{|c|}{6.4} & \multicolumn{2}{|c|}{27} & \multicolumn{2}{|c|}{9.9} & 0.7 & \\
\hline
\end{tabular}

The species used in the experiment was Cynodon dactylon [Pers] L. cultivar Tifway 419, known as bermudagrass. This grass is a result of an interspecific cross between common bermudagrass, Cynodon dactylon, and African bermudagrass, C. transvaalensis Burt-Davy (Christians, et al., 2016).

The experiment was conducted in a randomized block design, in a $2 \times 5$ factorial arrangement with 4 replicates. The treatments consisted of 2 correctives (steel slag and limestone) and 4 rates of the correctives, which were calculated to raise the soil base saturation of the $0-0.2-\mathrm{m}$ soil layer to $30 \%, 50 \%, 70 \%$ and $90 \%$, in addition to a control treatment that did not receive correction and showed $12 \%$ base saturation. The experimental plots measured $3 \times 4 \mathrm{~m}$, and the border area was $0.9 \mathrm{~m}$ at each border.

An analysis of the correctives was carried out following the methodology adapted from Brasil (2017), which revealed the following composition: dolomitic lime (1.0, $3.5,0.2,275.0,16.0$, and $3.5 \mathrm{~g} \mathrm{~kg}^{-1}$ of $\mathrm{N}, \mathrm{P}_{2} \mathrm{O}_{5}, \mathrm{~K}_{2} \mathrm{O}, \mathrm{Ca}$, $\mathrm{Mg}$, and $\mathrm{S}$, respectively; 600, 400, 20, 36800, 4800, and $50 \mathrm{mg} \mathrm{kg}-1$ of $\mathrm{Na}, \mathrm{B}, \mathrm{Cu}, \mathrm{Fe}, \mathrm{Mn}$, and $\mathrm{Zn}$, respectively; reactivity (RE) of $75.4 \%$; neutralizing power (NP) of $88 \%$; and relative total neutralizing power (RTNP) of 67\%; steel slag $\left(1.4,11.0,0.3,216.3,15.6,3.2 \mathrm{~g} \mathrm{~kg}^{-1}\right.$ of $\mathrm{N}, \mathrm{P}_{2} \mathrm{O}_{5}, \mathrm{~K}_{2} \mathrm{O}$, $\mathrm{Ca}, \mathrm{Mg}$, and $\mathrm{S}$, respectively, 600, 900, 30, 193500, 21500, 70, 90, and $193 \mathrm{mg} \mathrm{kg}^{-1}$ of $\mathrm{Na}, \mathrm{B}, \mathrm{Cu}, \mathrm{Fe}, \mathrm{Mn}, \mathrm{Zn}, \mathrm{Si}$, and $\mathrm{SiO}_{2}$ respectively; $71.1 \% \mathrm{RE}, 70 \% \mathrm{NP}$, and 50\% RTNP).

To prepare the area, the turfgrass was initially mown and then a $15 \mathrm{~cm}$ layer of soil was removed to reduce the seed bank of the forage present in the area and level the ground, using a bulldozer. Liming was performed according to each treatment by applying dolomitic limestone and steel slag manually to the soil surface and incorporating the material into the soil with a rotary hoe.

To plant the seedlings, furrows were made $0.30 \mathrm{~m}$ apart. Seedlings were obtained from sods cut in the size of $0.10 \times$ $0.40 \mathrm{~m}$. Time-of-planting fertilization was carried out in the furrow by using $160 \mathrm{~kg} \mathrm{ha}^{-1}$ of $\mathrm{P}_{2} \mathrm{O}_{5}$ and $35 \mathrm{~kg} \mathrm{ha}^{-1}$ of $\mathrm{N}$, in the form of monoammonium phosphate (MAP). Maintenance fertilizations were carried out in eight monthly applications throughout the crop cycle, using the 20-05-20 fertilizer, at the rate of $250 \mathrm{~kg} \mathrm{ha}^{-1}$ per application $(400,100$ and $400 \mathrm{~kg}$ $\mathrm{ha}^{-1}$ of $\mathrm{N}, \mathrm{P}_{2} \mathrm{O}_{5}$ and $\mathrm{K}_{2} \mathrm{O}$, respectively). The fertilizer was applied manually.

The area was irrigated using sprinklers, with frequency and volumes determined based on the soil water retention curve; and tensiometers, which were installed at the depths of 0.10 and $0.20 \mathrm{~m}$. Weeds (Brachiaria decumbens, Amaranthus deflexus, and Sonchus oleraceus) were controlled manually and by the turfgrass mowing.

Soil samples were collected at 174 days after transplantation (DAT). Ten subsamples were taken per plot to form a composite sample. Subsequently, $\mathrm{pH}$ in $\mathrm{CaCl}_{2}$, $\mathrm{OM}, \mathrm{P}_{\text {resin }}, \mathrm{Ca}, \mathrm{Mg}$ and $\mathrm{K}, \mathrm{H}+\mathrm{Al}^{+3}$ were determined (Raij et al., 2001). The Si content in the soil was determined using a $0.01 \mathrm{~mol} \mathrm{~L}^{-1}$ calcium chloride-based extractor (Korndörfer et al., 2004).

The ground cover rate of the turfgrass was evaluated by digital image analysis according to the methodology described by Godoy et al. (2012). This variable was determined at 71, 114, 161, and 208 DAT.

Plant dry matter mass was determined at the end of the cycle by collecting four samples per plot using a $6.8 \mathrm{~cm}$ diameter auger at a depth of $0.05 \mathrm{~m}$. The collected material was washed and later separated into leaves + stems and roots + stolons + rhizomes. These materials were then dried in a forced-air oven to determine their mass.

At 174 DAT, leaves were collected to determine the concentration of nutrients according to the methodology of Malavolta et al. (1997) and to measure the Si content of the leaf as proposed by Korndörfer et al. (2004).

Results were subjected to statistical analysis using Sisvar software (Ferreira, 2015). Regression was performed for the base saturations and the means test was applied to compare the correctives. 


\section{Results and Discussion}

\section{Soil chemical characteristics}

Six months after the application of the correctives in the 0-0.10 m layer of the soil, limestone was found to provide higher $\mathrm{pH}$ values than the slag, at the saturations of 50 and $90 \%$ (Table 2). The $\mathrm{pH}$ increased linearly with the increase in soil base saturation (BS), for the two correctives used. However, the $\mathrm{pH}$ increased by 0.27 and 0.22 units with each $10 \%$ increase in base saturation, as provided by limestone and slag, respectively, reaching 6.2 and 5.7, at the desired BS of $90 \%$. Similar results were obtained by Caetano et al. (2016), who compared the use of steel slag and limestone in the cultivation of maize.

Table 2. Chemical characteristics of the soil in the $0-0.10 \mathrm{~m}$ layer, according to the treatment of the experiment with bermudagrass.

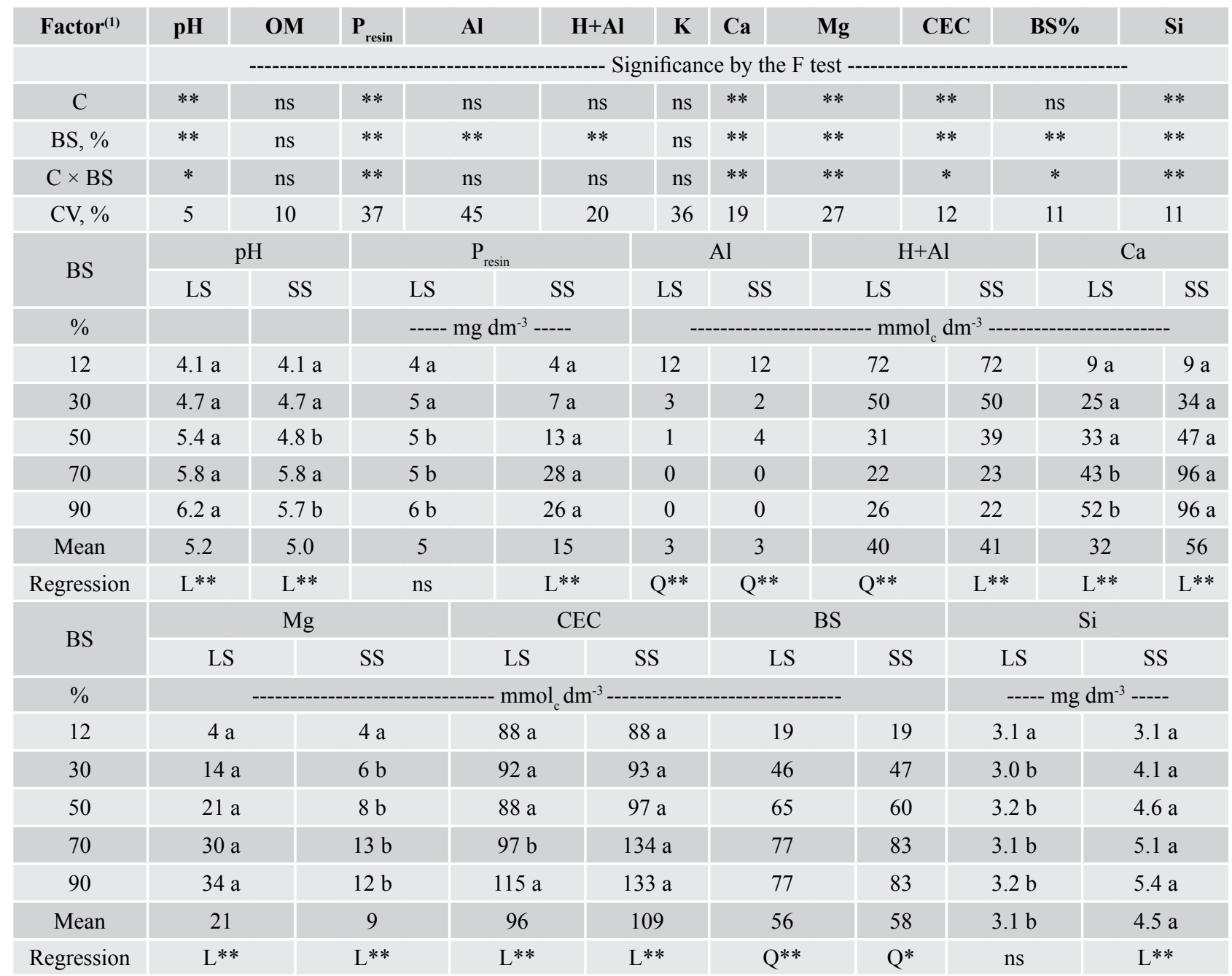

(1) C - corrective; BS - desired soil base saturation; LS - limestone; SS - steel slag; (2) Means followed by different lowercase letters in the same row differ statistically from each other by Tukey's test at $1 \%$ probability (3) L: linear effect; Q: quadratic effect; ns: not significant. *: $\mathrm{P}<0.05$; ** $\mathrm{P}<0.01$. Equation: $\mathrm{pH}$ limestone $\mathrm{y}=0.027 \mathrm{x}+3.8798 ; \mathrm{R}^{2}=0.98 ; \mathrm{pH}$ steel slag $\mathrm{y}=0.0219 \mathrm{x}+3.9163 ; \mathrm{R}^{2}=0.89 ; \mathrm{P}$ steel slag $\mathrm{y}=0.3322 \mathrm{x}+1.144 ; \mathrm{R}^{2}=0.89 ; \mathrm{Al}$ limestone $\mathrm{y}=0.0036 \mathrm{x}^{2}-0.507 \mathrm{x}+16.712 ; \mathrm{R}^{2}=0.95 ; \mathrm{Al}$ steel slag $\mathrm{y}=0.0026 \mathrm{x}^{2}-0.401 \mathrm{x}+15.048 ; \mathrm{R}^{2}=0.80 ; \quad \mathrm{H}+\mathrm{Al}$ limestone $\mathrm{y}=0.0123 \mathrm{x}^{2}-1.858 \mathrm{x}+93.281$; $\mathrm{R}^{2}=0.99 ; \mathrm{H}+\mathrm{Al}$ steel slag $\mathrm{y}=0.6449 \mathrm{x}+73.702 ; \mathrm{R}^{2}=0.92 ; \mathrm{Ca}$ limestone $\mathrm{y}=0.529 \mathrm{x}+5.7365 ; \mathrm{R}^{2}=0.98 ; \mathrm{Ca}$ steel slag $\mathrm{y}=1.2035 \mathrm{x}-4.2552 ; \mathrm{R}^{2}=0.93 ; \mathrm{Mg}$ limestone $\mathrm{y}=0.3869 \mathrm{x}+1.102 ; \mathrm{R}^{2}=0.98 ; \mathrm{Mg}$ steel slag $\mathrm{y}=0.1173 \mathrm{x}+2.6882 ; \mathrm{R}^{2}=0.89 ;$ CEC limestone $\mathrm{y}=0.3029 \mathrm{x}+80.735 ; \mathrm{R}^{2}=0.70 ; \mathrm{CTC}$ steel slag $\mathrm{y}=0.6708 \mathrm{x}+75.192 ; \mathrm{R}^{2}=0.85 ; \mathrm{BS} \%$ limestone $\mathrm{y}=-0.0121 \mathrm{x}^{2}+1.9804 \mathrm{x}-2.9365 ; \mathrm{R}^{2}=0.99 ; \mathrm{BS} \%$ steel slag $\mathrm{y}=-0.0093 \mathrm{x}^{2}+1.7825 \mathrm{x}-0.6284 ; \mathrm{R}^{2}=0.98 ;$ Silicate steel slag $\mathrm{y}=0.0284 \mathrm{x}+3.0269 ; \mathrm{R}^{2}=0.94$. 
In the two sampled layers, steel slag provided higher levels of $\mathrm{P}$ in the soil, at the calculated base saturations of $50 \%, 70 \%$ and $90 \%$, demonstrating greater efficiency in making this nutrient available as compared with limestone, which corroborates the descriptions of Barbosa Filho et al., (2004) and Caetano et al. (2016) (Tables 2 and 3 ). This result is related to the concentration of $P$ found in steel slag $\left(1.1 \% \mathrm{P}_{2} \mathrm{O}_{5}\right)$. Considering that the $\mathrm{P}$ content of limestone is $1 / 3$ of the value found in slag, an increase proportional to what occurred in the soil $\mathrm{P}$ for the slag should be observed. This fact was not observed, since the RTNP of the slag was $50 \%$, and thus a greater amount of corrective was required to promote the same effect as limestone. The increase in base saturation by the slag rates provided a linear increase of $3.3 \mathrm{mg} \mathrm{dm}^{-3}$ in $\mathrm{P}$ (resin) for each $10 \%$ increase in $\mathrm{BS}$.

Table 3. Chemical characteristics of soil in the $0.10-0.20 \mathrm{~m}$ layer, according to the treatment of the experiment with bermudagrass.

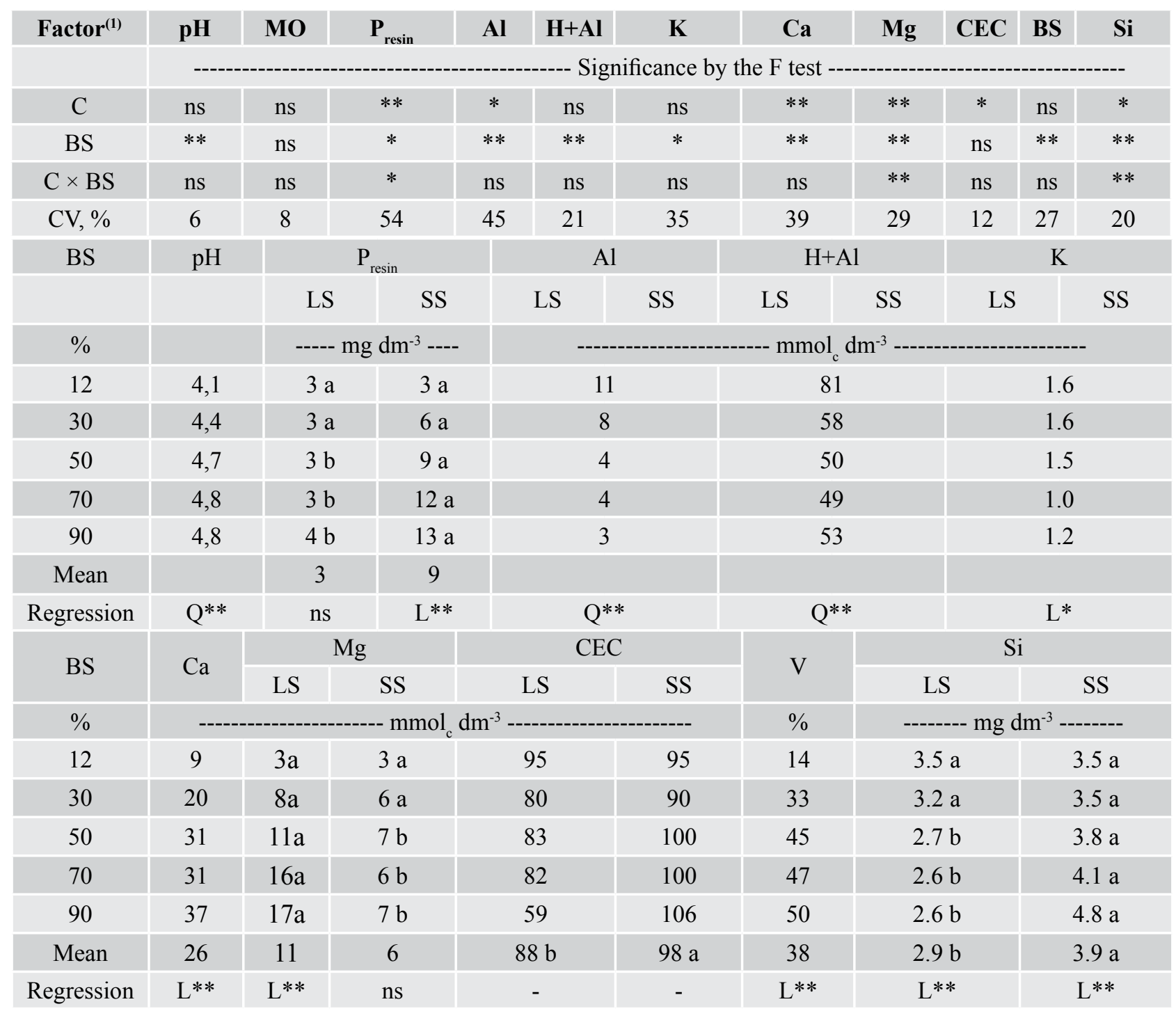

(1) C - corrective; BS - desired soil base saturation; LS - limestone; SS - steel slag; (2) Means followed by different lowercase letters in the same row differ statistically from each other by Tukey's test at $1 \%$ probability (3) L: linear effect; Q: quadratic effect; ns: not significant. *: $\mathrm{P}<0.05$; ** $\mathrm{P}<0.01$.

Equations: $\mathrm{pH}$ mean $\mathrm{y}=-0.0002 \mathrm{x}^{2}+0.0254 \mathrm{x}+3.8086 ; \mathrm{R}^{2}=0.99 ; \mathrm{P}$ steel slag $\mathrm{y}=0.1324 \mathrm{x}+1.9276 ; \mathrm{R}^{2}=0.97 ; \mathrm{Al}$ mean $\mathrm{y}=0.0016 \mathrm{x}^{2}-0.2646 \mathrm{x}+14.042$; $\mathrm{R}^{2}=0.97 ; \mathrm{H}+\mathrm{Al}$ mean $\mathrm{y}=0.0117 \mathrm{x}^{2}-1.5185 \mathrm{x}+96.052 ; \mathrm{K}$ mean $\mathrm{y}=-0.0072 \mathrm{x}+1.7414 ; \mathrm{R}^{2}=0.69 ;$ Ca mean $\mathrm{y}=0.34 \mathrm{x}+48.4625 ; \mathrm{R}^{2}=0.90 ; \mathrm{Mg}$ limestone $\mathrm{y}=0.1832 \mathrm{x}+1.7677 ; \mathrm{R}^{2}=0.96 ; \mathrm{SB}$ mean $\mathrm{y}=0.4114 \mathrm{x}+14.664 ; \mathrm{R}^{2}=0.92 ; \mathrm{BS} \%$ mean $\mathrm{y}=0.4352 \mathrm{x}+15.868 ; \mathrm{R}^{2}=0.83$. 
In the $0-0.10 \mathrm{~m}$ soil layer, there was no difference between the correctives in the neutralization of $\mathrm{Al}$ (Table 2). Regardless of the corrective agent, the soil Al content decreased as base saturation (as well as soil $\mathrm{pH}$ ) increased, and changed to an unaltered form (precipitate) when the soil $\mathrm{pH}$ reached 5.8. In the $0.10-0.20 \mathrm{~m}$ layer, because limestone raises the $\mathrm{pH}$ more, it resulted in lower $\mathrm{Al}$ contents than steel slag, on the average of the base saturation levels. There was also a reduction in soil Al values with the increasing rates, following the $\mathrm{pH}$ values (Table 3). As expected, potential acidity $(\mathrm{H}+\mathrm{Al})$ decreased in response to the corrective materials, with no differences observed between the means.

Both correctives induced an increase in the soil $\mathrm{Ca}$ and $\mathrm{Mg}$ contents as the rates were increased, which was also observed by Nunes et al. (2019). Between the correctives, limestone provided higher $\mathrm{Mg}$ levels in both soil layers, corroborating with Caetano et al. (2016), despite the similar amounts of this nutrient in their composition. Steel slag provided the highest $\mathrm{Ca}$ levels at base saturations greater than or equal to $70 \%$ in the uppermost layer and, on the average of the treatments with slag, in the layer of 0.10 to $0.20 \mathrm{~m}$ (Tables 2 and 3). Barbosa Filho, Zimmermann and Silva (2004) evaluated the application of slag in the rice crop and obtained similar results.

In the surface layer, base saturation increased until the calculated values of $82 \%$ and $96 \%$, for limestone and slag, respectively. In the $0.10-0.20 \mathrm{~m}$ layer, base saturation increased linearly, regardless of the corrective. When the average value of soil base saturation was calculated, in the 0.0-0.20 m layer, regardless of the corrective (BS of $40 \%$, $54 \%, 64 \%$, and $65 \%$ for the desired soil base saturations of $30 \%, 50 \%, 70 \%$, and $90 \%$, respectively), the saturations achieved were above those estimated in the treatments with the BS of $30 \%$ and $50 \%$. However, they were below those in the treatments with the BS of $70 \%$ and $90 \%$. Anjos et al. (2011) reported that the amounts of limestone calculated by the soil base saturation method were not sufficient to raise base saturation to the desired values, and that the effects of correction are more expressive in surface layer of 0.0 to $0.1 \mathrm{~m}$.

The highest available silicon levels in the soil were obtained with the application of steel slag (Tables 2 and
3). This result is explained by its chemical composition, which is able to make silicon available to the soil when compared with limestone. According to the rates calculated to increase predetermined base saturation levels, with the use of steel slag, the soil Si levels increased linearly in both evaluated layers, corroborating the findings of Barbosa Filho et al. (2004), Sobral et al. (2011) and Caetano et al. (2016). With the application of limestone, the Si content of the $0.0-0.10 \mathrm{~m}$ soil layer was not altered by base saturation. In the $0.10-0.20 \mathrm{~m}$ layer, a decreasing effect was seen, that is, the Si content declined as base saturation increased.

\section{Ground cover rate (GCR) of bermudagrass}

Until 71 DAT, the treatments had no effect on GCR due to the low solubility of the correctives and the mild temperatures in August and September, which reached average minimum values of 12.5 to $13{ }^{\circ} \mathrm{C}$ (Figure 1). Bermudagrasses are sensitive to low temperatures, ceasing to grow when the temperature is below $10^{\circ} \mathrm{C}$ and achieving optimum growth when the soil temperature is between 24 and $30^{\circ} \mathrm{C}$ (Christians et al., 2016).

At 114 DAT, with the increase in temperature and rainfall, a linear effect was observed, with the increasing soil base saturation values elevating GCR $(63.5 \%$ for limestone and $80 \%$ for steel slag) (Table 4). The slag provided higher GCR at the calculated saturations of $50 \%$, $70 \%$ and $90 \%$ when compared with limestone. The faster growth of bermudagrass in the slag treatments may be due to the supply of P (Tables 1 and 2) and Si. The presence of the silicate anion in the soil, from slag, can reduce the adsorption of the phosphate anion, making this nutrient more available to the plant (Souza and Chaves, 2015), which is very important for the growth of stolons and rhizomes in turfgrasses (Christians et al., 2016). In the treatments with the application of lime, the soil P content was very low, even though time-of-planting fertilization and topdressing were performed (Tables 1 and 2). The silicon present in the slag may have been useful to increase the resistance of the turfgrass to drought, as already observed by other authors (Bae et al., 2017; Hajiboland et al., 2017; Avila et al., 2019), since there was no rain in September and supplemental irrigation was not sufficient. 
Table 4. Ground cover rate (GCR) as a function of to the treatment at 71, 114, 161, and 208 days after transplantation of the bermudagrass (DAT).

\begin{tabular}{|c|c|c|c|c|c|c|c|c|}
\hline \multirow{4}{*}{$\begin{array}{c}\text { Soil base } \\
\text { saturation }\end{array}$} & \multicolumn{8}{|c|}{ Ground cover rate (CGR) } \\
\hline & \multicolumn{2}{|c|}{71 DAT } & \multicolumn{2}{|c|}{114 DAT } & \multicolumn{2}{|c|}{161 DAT } & \multicolumn{2}{|c|}{208 DAT } \\
\hline & \multicolumn{8}{|c|}{ Corrective } \\
\hline & LS & SS & $\mathbf{L S}$ & SS & LS & SS & LS & SS \\
\hline \multicolumn{9}{|c|}{$\%$} \\
\hline 12 & 14.8 & 14.8 & $48.3 \mathrm{a}$ & $48.3 \mathrm{a}$ & $90.8 \mathrm{a}$ & $90.8 \mathrm{a}$ & 98.7 & 98.7 \\
\hline 30 & 19.5 & 16.5 & $56.5 \mathrm{a}$ & $65.0 \mathrm{a}$ & $95.5 \mathrm{~b}$ & $97.5 \mathrm{a}$ & 99.0 & 99.2 \\
\hline 50 & 19.3 & 21.3 & $50.8 \mathrm{~b}$ & $73.3 \mathrm{a}$ & $95.3 \mathrm{~b}$ & $97.3 \mathrm{a}$ & 99.5 & 99.0 \\
\hline 70 & 14.3 & 20.8 & $53.5 \mathrm{~b}$ & $73.5 \mathrm{a}$ & $94.0 \mathrm{~b}$ & $96.8 \mathrm{a}$ & 99.5 & 99.0 \\
\hline 90 & 20.2 & 20.5 & $63.5 \mathrm{~b}$ & $80.0 \mathrm{a}$ & $93.0 \mathrm{~b}$ & $97.3 \mathrm{a}$ & 99.0 & 99.0 \\
\hline Mean & 17.4 & 18.8 & 54.5 & 68.0 & 93.7 & 95.9 & 99.0 & 99.2 \\
\hline Regression & ns & ns & $\mathrm{L}^{*}$ & $\mathrm{~L}^{* *}$ & $\mathrm{Q}^{* *}$ & $\mathrm{Q}^{* *}$ & ns & ns \\
\hline $\mathrm{CV}$ & 48.12 & & 21.46 & & 2.12 & & 0.47 & \\
\hline
\end{tabular}

LS - limestone; SS - steel slag; (1) Means followed by different lowercase letters in the same row differ statistically from each other by Tukey’s test at $1 \%$ probability (2) L: linear effect; Q: quadratic effect; ns: not significant. *: $\mathrm{P}<0.01$.

Equations: GCR at 114 DAT limestone $y=0.1394 x+47.497 ; R^{2}=0.54 ;$ GCR at 114 DAT steel slag $y=0.3639 x+49.679 ; R^{2}=0.85 ;$ GCR at 161 DAT limestone $y=-0.0023 x^{2}+0.2511 x+88.771 ; R^{2}=0.78 ;$ GCR at 161 DAT steel slag $y=-0.0024 x^{2}+0.3038 x+88.495 ; R^{2}=0.77$.

At 161 DAT, the turfgrasses of all treatments already covered more than $90 \%$ of the ground. However, statistical differences between the correctives and the saturation levels were still observed due to the low CV, with statistically superior results found with steel slag. The curves that express cover rate as a function of the doses showed quadratic responses, indicating GCR of $95.6 \%$ and $98.0 \%$ at the estimated saturations of $55 \%$ and $63 \%$ for limestone and slag, respectively (Table 4 ). Two parameters are considered most important for the formation of the sod: the time and the quality of the sod. Therefore, when it is possible to anticipate the cut, given the faster closing of the sod in the field, as was the case with steel slag, a very interesting and practical favorable effect is obtained. In addition, the faster the lawn closes in the production area, the fewer the problems with weeds, since a well-formed lawn reduces the possibility of these species developing.
At 208 DAT, both the limestone and slag treatments provided $99 \%$ ground cover by the turfgrass. In the treatment with no correction, GCR was $98 \%$, and the effect of the treatments was no longer observed (Table 4). For zoysiagrass, a GCR of $99 \%$ was achieved 398 days after the previous sod had been mown (Lima et al., 2018).

Leaf, stem, stolon, rhizome and root dry matter contents in bermudagrass

Dry matter accumulation was influenced by the treatments, and only the leaf + stem fraction was not significantly affected by the interaction (Table 5). The dry matter of leaves and stems increased linearly with base saturation when limestone was used, and quadratically when the slag was used, reaching the maximum value at $73 \%$ BS. The improvement in soil chemical attributes provided by the correctives explains the greater accumulation of dry matter by the turfgrass. 
Table 5. Dry matter of leaf + stem, rhizome + stolon and root at 281 days after transplantation of the bermudagrass.

\begin{tabular}{|c|c|c|c|c|c|c|}
\hline \multirow[t]{2}{*}{$\begin{array}{l}\text { Soil base } \\
\text { saturation }\end{array}$} & \multicolumn{2}{|c|}{$\begin{array}{c}\text { Leaf }+ \text { Stem } \\
(\mathbf{L}+\mathbf{S})\end{array}$} & \multicolumn{2}{|c|}{$\begin{array}{c}\text { Rhizome + Stolon } \\
(\mathbf{R}+\mathbf{S})\end{array}$} & \multicolumn{2}{|c|}{$\operatorname{Root}(\mathbf{R})$} \\
\hline & LS & SS & $\mathbf{L S}$ & SS & LS & SS \\
\hline$\%$ & \multicolumn{6}{|c|}{ 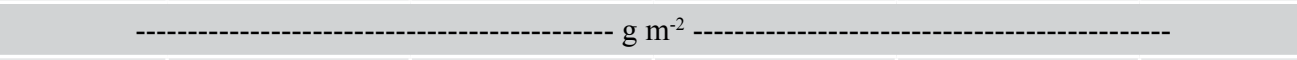 } \\
\hline 12 & $611 \mathrm{a}$ & $611 \mathrm{a}$ & $625 \mathrm{a}$ & $625 \mathrm{a}$ & $82 \mathrm{a}$ & $82 \mathrm{a}$ \\
\hline 30 & $884 \mathrm{a}$ & $950 \mathrm{a}$ & $650 \mathrm{a}$ & 677 a & $90 \mathrm{a}$ & $90 \mathrm{a}$ \\
\hline 50 & $721 \mathrm{a}$ & $1055 \mathrm{a}$ & $628 \mathrm{~b}$ & 983 a & $77 \mathrm{~b}$ & $143 \mathrm{a}$ \\
\hline 70 & $848 \mathrm{a}$ & $1027 \mathrm{a}$ & $675 \mathrm{~b}$ & $923 \mathrm{a}$ & $93 \mathrm{~b}$ & $148 \mathrm{a}$ \\
\hline 90 & $939 \mathrm{a}$ & $1107 \mathrm{a}$ & $705 \mathrm{~b}$ & $1228 \mathrm{a}$ & $96 \mathrm{~b}$ & $220 a$ \\
\hline Mean & 834 & 914 & 655 & 887 & 88 & 135 \\
\hline Regr. & $\mathrm{L}^{* *}$ & $\mathrm{Q}^{* *}$ & ns & $\mathrm{L}^{* *}$ & $\mathrm{~ns}$ & $\mathrm{~L}^{* *}$ \\
\hline $\mathrm{CV}$ & \multicolumn{2}{|c|}{17} & \multicolumn{2}{|c|}{16} & \multicolumn{2}{|c|}{30} \\
\hline
\end{tabular}

LS - limestone; SS - steel slag; (1) Means followed by different lowercase letters in the same row differ statistically from each other by Tukey’s test at $1 \%$ probability (2) L: linear effect; Q: quadratic effect; ns: not significant. *: $\mathrm{P}<0.01$.

Equations: $\mathrm{L}+\mathrm{S}$ limestone $\mathrm{y}=3.1278 \mathrm{x}+642.96 ; \mathrm{R}^{2}=0.53 ; \mathrm{L}+\mathrm{S}$ steel slag $\mathrm{y}=-0.1245 \mathrm{x}^{2}+18.085 \mathrm{x}+450.55 ; \mathrm{R}^{2}=0.91 ; \mathrm{R}+\mathrm{S}$ steel slag $\mathrm{y}=7.4198 \mathrm{x}+513.24$; $\mathrm{R}^{2}=0.88$; R steel slag $\mathrm{y}=1.7097 \mathrm{x}+50.43 ; \mathrm{R}^{2}=0.91$.

The treatments with slag had a very marked effect on dry matter accumulation in the stolons, rhizomes and roots, whose masses increased linearly with the increase in base saturation and reached twice the values obtained with control treatment when the highest dose of the corrective was used. The greater mass of dry matter accumulated in rhizomes and stolons provides greater resistance to traction in sods (Lima et al., 2018) and may result in increased yields at mowing by reducing the number of damaged sods, unsuitable for sale. Because of the limestone treatments did not influence dry matter accumulation in the rhizomes, stolons or roots, the effect of slag might have been due to the Si and P present in this corrective, since the other soil chemical attributes were similar between the two correctives. Silicon application significantly increased the photosynthetic rate, relative growth rate and water use efficiency of Kentucky bluegrass under water stress in response to improved water absorption and root growth and a more upright position of the leaves (Saud et al., 2014). Dakora and Nelwamondo (2003) also observed the effect of silicon on the growth of cowpea roots.

In addition to the already mentioned effects of the corrective, the higher responses to steel slag may be related to the presence of $\mathrm{Si}$ and the favorable effects of this element on plants. According to Godoy et al. (2012), Bermuda and Zoysia are the turfgrasses with the highest Si content, one of the characteristics that render them more resistant to traffic and trampling. This characteristic is related to the accumulation of Si just below the cuticle of the leaf and stems and to the increased lignin synthesis. No other effects related to the increase in the plant Si content were observed, such as greater tolerance to pathogens or pests; reduction of water losses due to transpiration; or changes in leaf architecture, increasing the incidence of radiation on the leaf. Nonetheless, some of these factors may have contributed to the greater mass production in the treatments with slag, which contains $\mathrm{Si}$.

\section{Nutrient concentration in the leaves}

The treatments influenced the N, Ca, Mg, B, Mn, and Si contents in the leaf blades of bermudagrass (Table 6). In terms of leaf $\mathrm{N}$, regression adjustment was only found for the slag, with the $\mathrm{N}$ content decreasing as base saturation was raised, which can be explained by the slower release of nutrients, including $\mathrm{N}$, in the treatments in which the corrective agents were not applied. This slower release provided $\mathrm{N}$ gradually, contrary to the treatments with higher doses, in which there was an increase in $\mathrm{pH}$ and, consequently, a more intense mineralization of plant residues (brachiaria) incorporated into the soil before the seedlings were planted, corroborating the findings of Yada et al. (2009). As a result, part of the $\mathrm{N}$ released quickly may have been lost by leaching, considering that the rainy season and this type of soil are factors that favor this type of loss. 
Table 6. Concentration of nutrients and $\mathrm{Si}$ in the leaf blade according to the treatment of the experiment with bermudagrass.

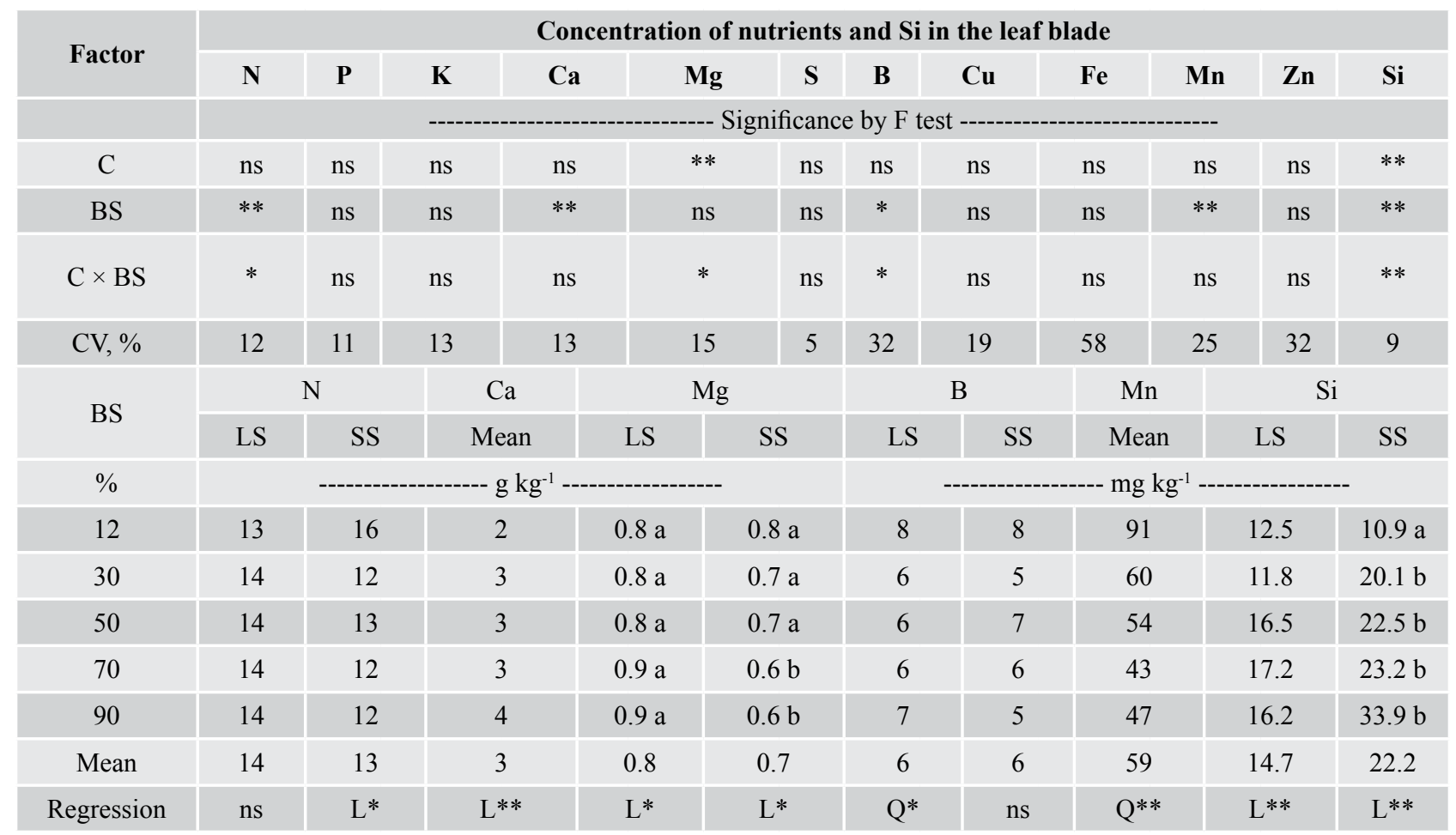

(1) C - corrective; BS - soil base saturation; LS - limestone; SS - steel slag; (1) Means followed by different lowercase letters in the same row differ statistically from each other by Tukey's test at $1 \%$ probability (2) L: linear effect; Q: quadratic effect; ns: not significant. *: $\mathrm{P}<0.05$; ** $\mathrm{P}<0.01$.

Equations: $N$ steel slag $y=-0.0401 x+15.02 ; R^{2}=0.51 ;$ Ca mean $y=0.0203 x+1.9771 ; R^{2}=0.79 ; M g$ limestone $y=0.0015 x+0.7624 ; R^{2}=0.76 ; M g$ steel slag $y=-0.002 x+0.808 ; R^{2}=0.88 ; B$ limestone $y=0.0016 x^{2}-0.12 x+9.1574 ; R^{2}=0.91 ;$ Mn mean $y=0.0125 x^{2}-1.8092 x+108.67 ; R^{2}=0.96 ;$ Si limestone $\mathrm{y}=0.0654 \mathrm{x}+11.544 ; \mathrm{R}^{2}=0.66 ;$ Si steel slag $\mathrm{y}=0.2497 \mathrm{x}+9.5363 ; \mathrm{R}^{2}=0.89$.

Another hypothesis is the so-called 'dilution effect', whereby plants that develop more intensely - due to better soil fertility conditions - dilute the absorbed nutrients through a larger mass. As a consequence, a lower concentration of these nutrients is observed in comparison with a control plant that did not undergo the same mass expansion (Table 6).

The Ca content in the leaf blade increased with the increasing doses of the correctives. No significant differences were found between the correctives, despite the difference in $\mathrm{Ca}$ availability in the soil between the corrective types (Tables 2 and 3). The corrective $\times$ saturation interaction effect was significant for the leaf $\mathrm{Mg}$ content, given the difference in the content of this element between the corrective agents, with greater values obtained with limestone. The highest leaf $\mathrm{Mg}$ levels were observed in the limestone treatments, at the highest doses, possibly because at lower doses the levels were not sufficient to alter the $\mathrm{Mg}$ concentration already existing in the soil. As observed for $\mathrm{N}$, the leaf Mg content in the slag treatments may have decreased linearly as base saturation was elevated, due to the greater growth of plant biomass in these treatments (Table 6).

The increasing in base saturation induced a decrease in the Mn concentration due to the change in the soil $\mathrm{pH}$, since the effect of reduced availability of cationic micronutrients with the increasing $\mathrm{pH}$ of the soil is well known in the literature.

Both by the type of corrective applied and the doses influenced the Si content of the leaf blade, whose higher levels were obtained with the treatments in which steel slag was used, at all applied doses (Table 6). Although no Si concentration was detected in limestone, the increasing doses led to a small increase in the leaf Si contents, indicating the requirement of this element by this turfgrass, which absorbed the available silicon in the soil.

Silicon contents in the plant tissue vary across species. In this sense, Si-accumulating plants are considered those whose $\mathrm{Si}$ content is greater than $10 \mathrm{~g} \mathrm{~kg}^{-1}$. Therefore, according to the results, bermudagrass is among the species considered Si accumulators. The Si levels observed in the leaf blade ranged from 10.9 to $33.9 \mathrm{~g} \mathrm{~kg}^{-1} \mathrm{DM}$, corroborating the data found by Nanayakkara et al., (2008) for ryegrass, in which the leaf silicon content reached $40 \mathrm{~g} \mathrm{~kg}^{-1} \mathrm{DM}$. Although the silicate doses increased gradually, the same was not true for the Si content of the plant, which increased by about $10 \mathrm{~g} \mathrm{~kg}^{-1}$ from the penultimate to the last applied dose. In order to explain this effect, it should be considered that, in addition to the $\mathrm{Si}$ from the applied silicate, its corrective effect may have increased the availability of the Si already present in the soil. 


\section{Conclusions}

Steel slag corrected the soil acidity similarly to limestone, in addition to increasing the soil $\mathrm{P}$ and $\mathrm{Si}$ contents. The most suitable base saturation for bermudagrass was $70 \%$, considering soil with a high CEC $\left(100 \mathrm{mmol}_{\mathrm{c}} \mathrm{dm}^{-3}\right)$. Steel slag provided greater dry matter accumulation in the stolons, rhizomes and roots than limestone. Therefore, it can confer greater resistance to the sod when mown and transplanted. It is suggested the use of steel slag and, in calculating the need for corrective, $90 \%$ soil base saturation.

\section{Author Contribution}

MRO: elaboration of the introduction, methodology and tables; interpretation and discussion of results. DMF: elaboration of the methodology and revision of the text. RLVB: elaboration of the methodology and revision of the text. CB: review of the manuscript, preparation of tables and figures, discussion of the results. LJGG: contribution in the introduction, statistical analysis, interpretation and discussion of results, and revision and formatting of the manuscript. AJMS: contribution to the discussion of results and formatting of the manuscript.

\section{Acknowledgement}

To the São Paulo State University (Unesp) for the space for the development of work, to the support of the Coordination for the Improvement of Higher Education Personnel - Brazil (CAPES), to the support of the National Council for Scientific and Technological Development $(\mathrm{CNPq})$, and to the support of the Tutorial Education Program (PET).

\section{References}

ALOVISI, A.M.T.; AGUIAR, G.C.R.; ALOVISI, A.A.; GOMES, C.F.; TOKURA, L.K.; LOURENTE, E.R.P.; MAUAD, M.; SILVA, R.S. Efeito residual da aplicação de silicato de cálcio e magnésio nos atributos químicos do solo e na produtividade da cana-soca. Agrarian, v.11, n.40, p.150-158, Dourados, 2018. DOI: http://dx.doi. org/10.30612/agrarian.v11i40.6241

ANJOS, J. L.; SOBRAL, L. F.; LIMA JUNIOR, M.A. Efeito da calagem em atributos químicos do solo e na produção da laranjeira. Revista Brasileira de Engenharia Agrícola e Ambiental, v.15, n.11, p.1138-1142, 2011.

ANTONIOLLI, D. Produção, regularização e conquistas do mercado de gramas cultivadas no Brasil. In: MATEUS, C. M. D. A.; VILLAS BÔAS, R, L.; ANDRADE, T. F.; OLIVEIRA, M. R.; BACKES, C.; GODOY, L. J. G. Tópicos atuais em gramado IV. Fundação de Estudos e Pesquisas Agrícolas e Florestais - Botucatu: FEPAF, 2015. p.9-22.
AVILA, R.G.; MAGALHÃES, P.C.; SILVA, E.M.; GOMES JÚNIOR, C.C.; LANA, U.G.P.; ALVARENGA, A.A.; SOUZA, T.C. Silicon supplementation improves tolerance to water deficiency in sorghum plants by increasing root system growth and improving photosynthesis. Silicon, v.11, n.6, s/p, 2019. DOI: http://dx.doi.org/10.1007/s12633-019$00349-5$

BAE, E.; HONG, A.; CHOI, S.; LEE, K.; PARK, Y. Silicon pretreatment alleviates drought stress and increases antioxidative activity in Kentucky Bluegrass. International Turfgrass Society Research Journal, v.13, n.1, p.591-600, 2017. DOI: http://dx.doi.org/10.2134/ itsrj2017.01.0059

BARBOSA FILHO, M.P.; ZIMMERMANN, F.J.P.; SILVA, O.F. Influência da escória silicatada na acidez do solo e na produtividade de grãos do arroz de terras altas. Ciência e Agrotecnologia, v.28, n.2, p.323-331, 2004. DOI: http:// dx.doi.org/10.1590/S1413-70542004000200011

BRASIL. MINISTÉRIO DA AGRICULTURA, PECUÁRIA E ABASTECIMENTO. Manual de métodos analíticos oficiais para fertilizantes e corretivos / Ministério da Agricultura, Pecuária e Abastecimento. Secretaria de Defesa Agropecuária. Brasília: MAPA, 2017. $240 \mathrm{p}$.

CAETANO, L.C.S.; PREZOTTI, L.C.; PACHECO, B.M.; GUARCONI, R.C. Características químicas do solo, produção de biomassa e teores de nutrientes e metais pesados em plantas de milho em função de doses de escória e de calcário. Revista Ceres, v.63, p.879-886, 2016. DOI: http://dx.doi.org/10.1590/0034-737x201663060018.

CHRISTIANS, N.E.; PATTON, A.J.; LAW, Q.D. Fundamentals of Turfgrass Management - Fifth Edition. New York: John Wiley \& Sons, 2016. 482p.

CUNHA, A.R.; MARTINS, D. Classificação climática para os municípios de Botucatu e São Manuel, SP. Irriga, v.14, n.1, p.1-11, 2009. DOI: 10.15809/irriga.2009v14n1p1-11.

DAKORA, F.D.; NELWAMONDO, A. Silicon nutrition promotes root growth and tissue mechanical strength in symbiotic cowpea. Functional Plant Biology, v.30, p.947953, 2003. http://dx.doi.org/10.1071/FP02161

FERREIRA, D.F. SISVAR: a computer analysis system to fixed effects split plot type designs. Revista Brasileira de Biometria, v.37, n.4, p.529-535, 2015.

GODOY, L.J.G.; BACKES, C.; VILLAS BÔAS, R.L.; SANTOS, A.J.M. Nutrição, adubação e calagem para produção de gramas. Botucatu: FEPAF, 2012, 146 p. 
HAJIBOLAND, R.; CHERAGHVAREH, L.; POSCHENRIEDER, C. Improvement of drought tolerance in Tobacco (Nicotiana rustica L.) plants by Silicon, Journal of Plant Nutrition, v.40, p.12, p.1661-1676, 2017. DOI: http://dx.doi.org/10.1080/01904167.2017.1310887.

KORNDÖRFER, G.H.; PEREIRA. H.S.; NOLLA. A. Análise de silício: solo, planta e fertilizante. Uberlândia: GPSi/ICIAG/ UFU, 2004. 34 p. (Boletim Técnico, 2).

LIMA, C.P.; BACKES， C.; SANTOS， A.J.M.; FERNANDES, D.M.; VILLAS BÔAS, R.L.; OLIVEIRA, M.R. Quantidade de nutrientes extraídos pela grama bermuda em função de doses de nitrogênio. Bioscience Journal, v.31, n.5, p.1432-1440, Sept./Oct. 2015. DOI: https://doi.org/10.14393/BJ-v31n5a2015-21967.

LIMA, C.P.; BACKES, C.; SANTOS, A.J.M.; VILLAS BÔAS, R.L.; FERNANDES, D.M.; GODOY, L.J.G.; OLIVEIRA, M.R. Sod production and the effects of liquid organo-mineral fertilizers and thickness of sod. Scientia Agricola, v.75, p.346-353, 2018. DOI: https://doi. org/10.1590/1678-992x-2016-0320.

MALAVOLTA, E.; VITTI, G.C.; OLIVEIRA, S.A. Avaliação do estado nutricional das plantas: princípios e aplicações. 2ed. Piracicaba: POTAFOS, 1997. 319p.

NANAYAKKARA, U.N., UDDIN, W.; DATNOFF, L. E. Application of silicon sources increases silicon accumulation in perennial ryegrass turf on two soil types. Plant Soil, v.303, p.83-94, 2008. DOI: https://doi. org/10.1007/s11104-007-9488-x

NUNES, A.B.C.; SAGGIN JÚNIOR, O.J.; SILVA, E.M.R.; PINTO, F.A.; SANTOS, J.V.; CARNEIRO, M.A.C. Steel slag and phosphate nutrition of corn inoculated with arbuscular mycorrhizal fungi. Pesquisa Agropecuária Brasileira, v.54, p.1-9, 2019. DOI: https://dx.doi. org/10.1590/s1678-3921.pab2019.v54.00096
RAIJ, B. van; ANDRADE, J. C.; CANTARELLA, H.; QUAGGIO, J.A. Análise química para avaliação da fertilidade de solos tropicais. Campinas: Instituto Agronômico, 2001. 285p.

RODRIGHERO, M.B.; BARTH, G.; CAIRES, E.F. Aplicação Superficial de Calcário com Diferentes Teores de Magnésio e Granulometrias em Sistema Plantio Direto. Revista Brasileira de Ciência do Solo, v.39, p.17231736, 2015. DOI: http://dx.doi.org/10.1590/01000683rb cs20150036.

SANTOS, H.G.; JACOMINE, P.K.T.; ANJOS, L.H.C.; OLIVEIRA, V.A.; LUMBRERAS, J.F.; COELHO, M.R.; ALMEIDA, J.A.; ARAÚJO FILHO, J.C.; OLIVEIRA, J.B.; CUNHA, T.J.F. Sistema brasileiro de classificação de solos. 5ed., Brasília: Embrapa, 2018. 356p.

SAUD, S; LI, X.; CHEN, Y.; ZHANG, L.; FAHAD, S.; HUSSAIN, S.; SADIQ, A.; CHEN, Y. Silicon application increases drought tolerance of Kentucky bluegrass by improving plant water relations and morphophysiological functions. The Scientific World Journal, v.2014, p.1-10, 2014. DOI: http://dx.doi.org/10.1155/2014/368694.

SOBRAL, M.F.; NASCIMENTO, C.W.A; CUNHA, K.P.V.; FERREIRA, H.A.; SILVA, A.J.; SILVA, F.B.V. Escória de siderurgia e seus efeitos nos teores de nutrientes e metais pesados em cana-de-açúcar. Revista Brasileira de Engenharia Agrícola e Ambiental, v.15, p.867-872, 2011. DOI: http://dx.doi.org/10.1590/S141543662011000800015

SOUZA, R.S.; CHAVES, L.H.G. Efeito do agrosilício e calcário na disponibilidade de fósforo em Argissolo e Latossolo. Magistra, v.27, n.1, p.1-13, 2015.

YADA, M.M.; POÇAS, E.C.; TEIXEIRA, E.M.K.; BALOTA, E.L.; PARRA, M.S. Efeito da adição de silicato na mineralização do carbono e do nitrogênio. Revista Brasileira de Agroecologia, v.4, n.2, 2009. 